シンポジウム 2 : 司会の言葉

\title{
The role of mucin in acute or chronic sinonasal inflammation
}

Chang Hoon $\mathrm{Kim}^{1}$, 清水 猛史 ${ }^{2}$

${ }^{1}$ Yonsei University, Korea

2 滋賀医科大学

鼻副鼻腔の粘液層は，粘液線毛輸送機能による異物の排除，有毒ガスの中和と希釈などにより粘膜 を保護するとともに, 吸気の加湿加温や各種の炎症反応の場としての作用を有している。細菌・ウイ ルス感染やアレルギー性炎症, 物理化学的刺激などにより粘液が産生され, 杯細胞や粘膜下腺の増生 が生じる。過剩な粘液産生は鼻漏になり, 粘液線毛輸送機能の破綻や炎症の遷延化・慢性化の一因に なる。粘液の主な構成成分である厶チンは巨大な高分子糖蛋白で, コア蛋白のセリンとスレオニンに Oーグルコシド結合により多数の糖残基が結合している。現在, ヒトでは約 20 種類のムチンのコア蛋 白となる MUC 遺伝子が複数の染色体上に見つけられている。ムチン蛋白には分泌型と膜結合型があ り，分泌型ムチンは物性的にゲルを形成する gel-forming タイプと non gel-forming タイプに分けら れる。気道においてはこのうち MUC2, MUC5AC, MUC5B などが分泌型 gel-forming ムチンとして 炎症に応じてその産生が増加することが知られている。分泌型 non gel-forming には MUC7 があり, 特に杯細胞では MUC5AC, 粘膜下腺の粘液細胞で MUC5B, 漿液細胞で MUC7 など細胞によって異 なったムチンの発現が報告されている。気道における膜結合型ムチンには MUC1, MUC4, MUC11, MUC13 などがあり, 病原体の受容体としての作用や細胞の接着, シグナル伝達などの多彩な作用を 担っている。本シンポジウムでは, 鼻副鼻腔炎症におけるムチンの役割について, ムチン研究の世界 的第一人者である Temple 大学の Kwang Chul Kim 教授に基調講演をお願いし, 次いで滋賀医科大学 の清水志乃先生, 三重大学の石永一先生, Yonsei 大学の Chang Hoon Kim 先生にそれぞれの立場か ら，臨床への還元を目指したご講演をいただく予定である。 


\title{
Role of MUC1 mucin during the respiratory track infection and inflammation
}

\author{
K. Chul Kim
}

Temple University Lung Center, Philadelphia, Pennsylvania, USA

Airway mucins are high molecular weight glycoproteins that are thought to play an important defensive role against inhaled pathogens. Twenty mucin genes (MUC in human and Muc in nonhuman species) have been cloned, ten of which are expressed in the respiratory track (RT). Why so many mucins are expressed in the RT, however, remains unknown. To date, the only mucin gene product whose function is known in the RT is MUC1 which has been shown to play an important counter-regulatory role during airway inflammation. While inflammation is an essential host defense mechanism against invading pathogens, the inflammatory response needs to be controlled once pathogens are cleared to avoid unnecessary damage to the host. MUC1 appears to mediate one of the mechanisms through which airway inflammation is controlled. (Kim and Lillehoj, Am J Respir Cell Mol Biol 39 : 644, 2008). In this lecture, I will focus on the role of MUC1 mucin in the context of airway inflammation. MUC1 is expressed on the surface of mucosal epithelial cells as well as hematopoietic cells. The anti-inflammatory role of MUC1 is best illustrated using an airway Pseudomonas aeruginosa (PA) infection model. Briefly, PA entering the airway is recognized by various TLRs on the epithelial cells which results in the release of inflammatory mediators such as IL -8 and TNF- $\alpha$ which, in turn, recruit neutrophils inducing airway inflammation. Inflammatory products such as neutrophil elastase and $\mathrm{TNF}-\alpha$ increase the levels of epithelial MUC1 thereby suppressing TLR signaling and ending the ongoing inflammatory response. Failure to upregulate MUC1 may result in a continuous influx of neutrophils into airways leading to injuries and remodeling of the airways, a major phenotype seen in COPD. MUC1 mucin seems to play a key role at the later stages of inflammation to prevent host damage through both the timely appearance and highly efficient intervention of the inflammatory mechanism. 


\title{
ROS and Human Airway Mucus
}

\author{
OChang Hoon Kim, ${ }^{1,2}$ Joo-Heon Yoon ${ }^{1,2,3,4}$ \\ ${ }^{1}$ Department of Otorhinolaryngology \\ ${ }^{2}$ The Airway Mucus Institute \\ ${ }^{3}$ Research Center for Human Natural Defense System (RCHNDS) \\ ${ }^{4}$ BK21 Project for Medical Science, Yonsei University College of Medicine, Seoul, Korea
}

Mucus hypersecretion is a prominent manifestation in patients with chronic inflammatory airway diseases, and MUC5AC is a major airway mucin. It is well known that reactive oxygen species (ROS) may be involved in the pathogenesis of various inflammatory airway diseases. The purpose of this study was to identify which secreted mucin genes are induced by exogenous hydrogen peroxide and the mechanism by which these genes are up-regulated in normal human nasal epithelial (NHNE) cells. Exogenous $\mathrm{H}_{2} \mathrm{O}_{2}$ induced the ligand independent activation of epidermal growth factor receptors (EGFR) and subsequent activation of ERK1 mitogen-activated protein kinase, resulting in the induction of intracellular ROS generation. Through this signal pathway, exogenous $\mathrm{H}_{2} \mathrm{O}_{2}$ markedly induced overexpression of the MUC5AC gene. In addition, Nox4, a subtype of nonphagocytic NADPH oxidase, was found to play a key role in intracellular ROS generation and exogenous $\mathrm{H}_{2} \mathrm{O}_{2}$-induced MUC $5 \mathrm{AC}$ gene expression in NHNE cells. 


\title{
Role of the coagulation system in mucin production of sinonasal inflammation
}

\author{
Shino SHIMIZU
}

Department of Otorhinolaryngology, Shiga University of Medical Science

Thrombin is an effector enzyme of the coagulation system with important biological functions not only in thrombosis and hemostasis but also in inflammation. The precise role of thrombin in sinonasal inflammation remains unknown but indirect evidence suggests that it may play a fundamental role. We found that thrombin contributed to tissue remodeling by stimulating the secretion of platelet-derived growth factor (PDGF) and the proliferation of fibroblasts or smooth muscle cells. The natural anticoagulant-activated protein $\mathrm{C}$ decreased the PDGF expression and suppressed the fibrosis in the mouse model of lung fibrosis.

This study was conducted to explore whether thrombin is presence in upper airways, if so, whether it affects mucin secretion. Patients with allergic rhinitis or chronic sinusitis were enrolled in the clinical study. Primary nasal epithelial cells, normal bronchial epithelial cells and airway epithelial cell lines were used for in vitro evaluation, and rats as in vivo animal models.

Significant concentrations of thrombin were found in nasal secretion after allergic provocation in patients with nasal allergy and in nasal secretion of patients with chronic sinusitis. Airway epithelial cells expressed thrombin receptors (PAR-1, PAR-3, and PAR-4). Thrombin and its agonistic receptor peptide induced significant secretion of MUC5AC in primary nasal cells, normal bronchial epithelial cells and airway epithelial cell lines. Thrombin also induced the expression of epidermal growth factor receptor (EGFR) in nasal epithelial cells. Intranasal instillation of thrombin induced hypertrophic and metaplastic changes of goblet cells in rat nasal epithelium. Activated protein $\mathrm{C}$ and heparin are reported to have anti-inflammatory functions in addition to their regulatory action in the clotting system. Both activated protein $\mathrm{C}$ and heparin suppressed MUC5AC and IL-8 production from airway epithelial cells. Intranasal instillation of activated protein $\mathrm{C}$ significantly inhibited thrombininduced mucus production in rat nasal epithelium. Intranasal instillation of heparin also inhibited LPS-induced mucus production in rats.

These results suggest that activation of the coagulation system occurs during the sinonasal inflammation and that thrombin plays a crucial role in the regulation of mucin production. Anti-coagulant drugs such as activated protein $\mathrm{C}$ and heparin may provide a new therapeutic strategy in sinonasal inflammation. 


\section{The role of TGF-alpha for eosinophilic sinusitis}

\section{OHAJIME ISHINAGA, KAZUHIKO TAKEUCHI}

Department of Otorhinolaryngology, Head and Neck Surgery,

Mie University Graduate School of Medicine

(Background) Eosinophilic sinusitis (ES) is intractable sinusitis characterized by the presence of a highly viscous rhinorrhea. ES is a chronic inflammatory condition of the airway with prominent eosinophilic infiltration. However, it is still unknown what cause mucin overproduction in ES. In this study, we hypothesized that TGF-alpha play an important role for the pathogenesis of ES, especially for mucin gene over expression. (Methods) 1) Immunofluorescence staining has been performed for detection of the TGF-alpha expression level in middle turbinate biopsy from a patient with chronic sinusitis or with ES, comparing with normal patients. 2) Next, TGF-alpha induced mucin gene expression was assessed by using luciferase assay in human cultured epithelial cells. 3) Furthermore, we also investigated the mechanism by which TGF-alphainduced mucin gene expression, and interaction with other cytokines was assessed by using luciferase assay with several chemical signal inhibitors in vitro. (Results and Discussions) 1) The expression level of TGF-alpha by immunofluorescence staining is now under the investigation, and we will report the detail of these results at the time of the symposium. 2) TGF-alpha statistically induced both MUC2 gene and MUC5AC gene expression in human epithelial cells. 3) Regarding to the mechanism, TGF-alpha up regulated MUC2 gene through EGF signaling. On the other hand, p38 MAPK pathway was negatively involved in TGFalpha induced MUC2 expression. TGF-alpha also induced MUC5AC expression via EGF signaling but not p38 pathway. We have investigated the interaction of TGF-alpha with other inflammatory cytokine TNF-alpha. Interestingly, TGF-alpha synergistically enhanced TNF-alpha induced both MUC2 gene and MUC5AC gene expression, respectively. We will further investigate the mechanism of this interaction. 